\title{
Sistem Informasi Pembelajaran Daring Dengan Metode Learner-Led Learning
}

\author{
Herlambang Brawijaya ${ }^{1}$, Samudi Samudi ${ }^{2, *}$, Slamet Widodo ${ }^{1}$ \\ 1 Sistem Informasi; Universitas Bina Sarana Informatika; Jalan Kramat Raya no.98, Senen, \\ Jakarta Pusat 10450; (021) 23231170; e-mail: herlambang.hba@bsi.ac.id, \\ slamet.smd@bsi.ac.id \\ 2 Sistem Informasi; Universitas Nusa Mandiri; Jalan Jatiwaringin Raya No.2, Jakarta Timur, \\ (021) 28534471; e-mail: samudi.smx@nusamandiri.ac.id \\ * Korespondensi: e-mail: samudi.smx@nusamandiri.ac.id
}

Diterima: 28 Oktober 2021; Review: 15 Nopember 2021; Disetujui: 17 Nopember 2021

Cara sitasi: Brawijaya H, Samudi S, Widodo S. 2021. Sistem Informasi Pembelajaran Daring Dengan Metode Learner-Led Learning. Bina Insani ICT Journal. Vol. 8 (2): 156-165.

\begin{abstract}
Abstrak: Teknologi modern semakin pesat perkembangannya, sebagai masyarakat kita dapat merasakan hal positif dari perkembangan teknologi modern, salah satunya adalah internet. Memanfaatkan internet dengan hal positif dapat mempermudah kegiatan masyarakat, seperti dalam bidang pendidikan salah satunya adalah kegiatan belajar mengajar. Dengan adanya kegiatan belajar mengajar dapat menambah wawasan dan ilmu pengetahuan bagi masyarakat, akan tetapi terkadang pelajar bahkan pengajar yang melaksanakan kegiatan belajar mengajar tersebut terlalu terkekang oleh waktu dan peraturan yang berlaku pada tempat belajarnya. Hasil permasalahan yang penulis dapatkan pada kegiatan belajar mengajar konvensional adalah diharuskannya meluangkan waktu untuk pergi ke tempat belajar dan juga ditentukan durasi belajar mengajarnya bahkan diadakan peraturan yang terkadang membuat peserta sampai pengajar tidak nyaman dengan peraturan tersebut. Oleh karena itu penulis tertarik untuk menyelesaikan permasalahan tersebut dengan membuat sistem informasi pembelajaran (elearning) dengan metode learner-led learning berbasis web yang dapat diakses dimanapun dan kapanpun tanpa mengeluarkan biaya dan tidak terkekang oleh waktu. Penelitian ini diharapkan dapat membantu dalam proses belajar mengajar dengan nyaman. Website ini juga menyediakan fasilitas seperti materi yang bersifat video dan artikel yang bertujuan bagi pelajar yang lebih nyaman belajar dengan video interaktif dan juga tersedia fasilitas sertifikat sebagai bukti bahwa pelajar telah berhasil dalam menyelesaikan soal dari materi yang dipelajarinya.
\end{abstract}

Kata kunci: pelajar, pembelajaran daring, pengajar, sistem pembelajaran, website

Abstract: Modern technology is growing rapidly, as a society we can feel positive things from the development of modern technology, one of which is the internet. Using the internet with positive things can facilitate community activities, such as in the field of education, one of which is teaching and learning activities. With teaching and learning activities, it can add insight and knowledge to the community, but sometimes students and even teachers who carry out teaching and learning activities are too constrained by time and the regulations that apply to the place of study. The results of the problems that the authors get in conventional teaching and learning activities are that they are required to take the time to go to the place of study and also determine the duration of teaching and learning and even make regulations that sometimes make participants until the teacher is not comfortable with these rules. Therefore, the authors are interested in solving these problems by creating a learning information system (e-learning) with a web-based learner-led learning method that can be accessed anywhere and anytime without incurring costs and not being constrained by time. This research is expected to help in the teaching and learning process comfortably. This website also provides facilities such as video materials and articles aimed at making students more comfortable learning with 
interactive videos and certificate facilities are also available as evidence that students have succeeded in solving problems from the material they have studied.

Keywords: e-learning, learning system, student; teacher, website

\section{Pendahuluan}

Pendidikan merupakan salah satu hal yang penting dalam kehidupan kita, karena pendidikan biasanya menjadi salah satu hal yang menentukan masa depan kita ketika tiba saatnya masuk ke dalam dunia kerja. Metode yang paling umum digunakan di dalam dunia pendidikan adalah dengan sistem pembelajaran dengan metode tatap muka, dimana proses belajar mengajar hanya dapat dilakukan dengan syarat [1]. Jika kedua belah pihak tidak bertemu maka proses belajar mengajar tidak dapat dilaksanakan. Metode ini biasanya di temukan pada sekolah-sekolah ataupun pendidikan formal lainnya yang membutuhkan adanya interaksi langsung antara pengajar dan pelajar dalam waktu dan tempat yang sama.

Pemerintah sudah berupaya dalam meningatkan kualitas pendidikan, akan tetapi masih banyak kekurangan pada sistem pendidikan itu sendiri, seperti siswa yang menggunakan sistem pendidikan konvensional seperti terpusat pada guru dan hanya terfokus pada pembelajaran dikelas, dimana siswa hanya mendengar dan mencatat dan terkekang oleh waktu yang [2]. Dalam memanfaatkan teknologi informasi dalam dunia pendidikan adalah [3]. Sistem e-learning dapat diterapkan dalam interaksi virtual jarak jauh antara pengajar dan siswa ataupun pendidikan konvensional yang berinteraksi secara [4][5].

Dalam upaya meningkatkan efektivitas dan efesiensi dalam bidang pendidikan, maka dibuat perubahan konsep belajar mengajar dari tatap muka secara langsung ke arah konsep elearning yang dapat mempermudah proses belajar dan mengajar lebih fleksibel, efesien dan efektif[6], [7]. Untuk mendapatkan solusi dari permasalahan dengan metode tatap muka, elearning menjadi solusi yang tepat untuk memberikan solusi dari permasalahan tersebut[8]. Dengan e-learning secara umum pengajar dan pelajar tidak perlu hadir di dalam tempat yang sama, melainkan mereka dapat bertemu secara virtual di internet untuk melakukan aktifitas belajar mengajar[9][10]. Permasalahan dari metode tersebut adalah pelajar dan pengajar harus online di internet secara bersamaan dan bertemu di suatu tempat diskusi atau ruang kelas virtual [11].

Untuk memberikan solusi dari permasalahan e-larning secarara umum yaitu dengan cara e-learning dengan metode Learned-led Learning atau dikenal dengan metode Self-directed Learning [12]. Salah satu jenis e-learning adalah Learner-led Learning yaitu metode dimana pengajar tidak perlu online pada waktu yang sama untuk menyampaikan materi kepada pelajar [12]. Karena dengan metode Learner-led, para pemberi materi telah menyiapkan materi yang disampaikan sebelumnya di website tersebut dan pelajar dapat mendapatkan materi yang disampaikan dengan mudah dan tidak terbatas oleh waktu tertentu. Pada saat ini, banyak situs belajar online yang telah menerapkan metode ini [13]. Tetapi, mayoritas dari situs-situs tersebut merupakan situs belajar online luar negeri dimana bahasa yang digunakan adalah universal yaitu bahasa inggris dan komunitas pelajar di situs-situs tersebut juga terbiasa menggunakan bahasa inggris saat berkomunikasi atau berdikusi kepada sesama pelajar.

Menurut du Toit-Brits [14], pembelajaran dengan metode Self-Directed Learning (SDL) merupakan metode yang diakui baik dalam merubah metode pembelajaran yang ada. Hal ini dkarenakan dapat menimbulkan karakteristik mandiri pada diri pelajar. Ketika pelajar memiliki karakteristik mandiri, mereka mampu mengelola kebutuhan Pendidikan yang mereka butuhkan dan mereka mampu berpikir kritis dan bertanggung jawab.

Menurut Khiat [15], metode Self-Directed Learning (SDL) di zaman sekarang cukup penting terutama bagi pelajar yang berusia dewasa dimana aktifitas mereka tidak hanya sebagai pelajar tetapi juga sebagai pekerja. Metode ini memungkinkan pelajar untuk mengamankan pembelajaran dari ketertinggalan dan proses pembelajaran pun menjadi relevan dengan sumber daya pelajar.

Menurut Sumuer [16], penerapan Self-Directed Learning (SDL) pada tingkat perguruan tinggi memiliki tujuan penting untuk dapat meningkatkan kualitas pembelajaran dan persiapan karakteristik mahasiswa untuk masa depan yang mencakup otonomi pibadi, tanggung jawab dan pertumbuhan pribadi.

Berdasarkan uraian dari penelitian sebelumnya tersebut, maka metode Learner-Led Learning atau Self-Directed Learning (SDL) dapat digunakan untuk merancang sistem 
pembelajaran yang dilakukan secara daring (E-Learning). Sistem Pembelajaran secara daring ini dibangun menggunakan framework Codelgniter dan basis data MySQL.

\section{Metode Penelitian}

Metodologi yang digunakan dalam penelitian ini yaitu metode air terjuan (waterfall mode/). Metode ini digunakan karena dapat memetakan pengembangan sistem dan proses bisnis dengan baik dan mudah untuk dipahami[17]. Tahapan penelitian dari metode ini dapat dilihat pada gambar 1.

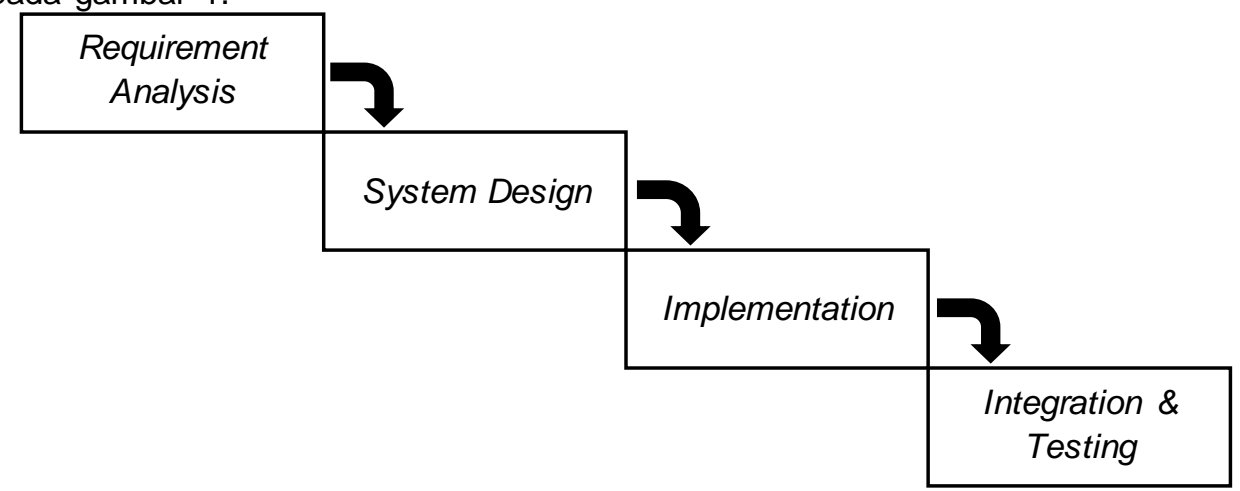

Sumber: Hasil Penelitian (2021)

Gambar 1. Tahapan Penelitian

Berdasarkan gambar 1 diatas, dapat dijelaskan tahapan penelitian dalam Sistem Informasi Pembelajaran Daring sebagai berikut:

\section{Requirement Analysis}

Tahap pertama melakukan analisa terhadap kebutuhan dalam membuat perancangan web e-learning. Pengguna yang terlibat ada 3 , yaitu pengajar, pelajar dan admin. Pengajar adalah yang mengelola data kursus dan siswa dan dapat mengubah, menambah dan menghapus data tersebut. Pelajar adalah seseorang yang memiliki akun yang telah terdaftar pada website yang dapat mengikuti kursus dan belajar dari kursus tersebut. Sedangkan admin adalah yang mengelolah data dan dapat mengubah, menambah dan mengapus data tersebut.

\section{System Design}

Setelah tahap requirement analysis terpenuhi, maka tahapan selanjutnya dilakukan proses system design dengan membagi kebutuhan perangkat keras (hadware) dan perangkat lunak (software). Proses ini terfokus pada rancangan antar muka, rancangan basis data, dan rancangan struktur navigasi. Rancangan antar muka yang meliputi rancangan untuk pelajar, pengjar dan admin. Sedangkan rancangan basis data meliputi Entity Relationship Diagram, Logical Record Structure dan Spesifikasi File.

\section{Implementation}

Pada tahap ini mulai dilakukan penterjemahan dari system design kebentuk program yang nantinya akan digunakan dalam proses pembelajaran. Sistem ini di bangun dengan menggunakan bahasa pemograman PHP, CSS, Javascript, Framework Codeigniter dan menggunakan aplikasi basis data, seperti MySQL.

\section{Integration \& Testing}

Dalam tahap integrasi dan pengujian ini dilakukan uji coba terhadap semua modulmodul yang sudah dibuat sebagai bahan acuan agar aplikasi yang akan dibuat lebih baik dan berfungsi sebagaimana mestinya.

\section{Hasil dan Pembahasan}

\section{Identifikasi Kebutuhan Sistem}

Tahapan analisis kebutuhan adalah tahap untuk mengidentifikasi apa yang diperlukan, dibutuhkan dan diinginkan oleh para pengguna. Dalam hal ini pengguna dapat dibedakan menjadi tiga, yaitu: 
Kebutuhan Pelajar seperti pelajar dapat memilih kursus yang akan di ikuti. Pelajar dapat memilih kursus sesuai kategori kursus. Pelajar dapat mengisi dan mengubah profil pelajar. Pelajar dapat melakukan login dengan menggunakan akun yang telah dibuat sebelumnya. Pelajar dapat melakukan kegiatan belajar pada masing-masing kursus yang telah dia daftarkan.

Kebutuhan pengajar seperti pengajar dapat membuat, mengubah dan menghapus kursus, pengajar dapat mengisi dan mengubah profil pengajar, pengajar dapat mengelola data pelajar yang mengikuti kursus, pengajar dapat melakukan login dengan menggunakan akun yang telah dibuat.

Kebutuhan Admin seperti Admin dapat menambah, mengubah dan menghapus data admin, admin dapat menambah, mengubah dan menghapus data kategori, admin dapat mengubah dan menghapus data pelajar, admin dapat menghapus data pengajar, admin dapat melihat, mengubah dan menghapus data kursus, admin dapat melihat laporan kursus.

\section{Entity Relationship Diagram}

Langkah berikutnya penyusunan Entity Relationship Diagram sebagai representasi dari database yang akan digunakan dalam perancangan sistem informasi ini.

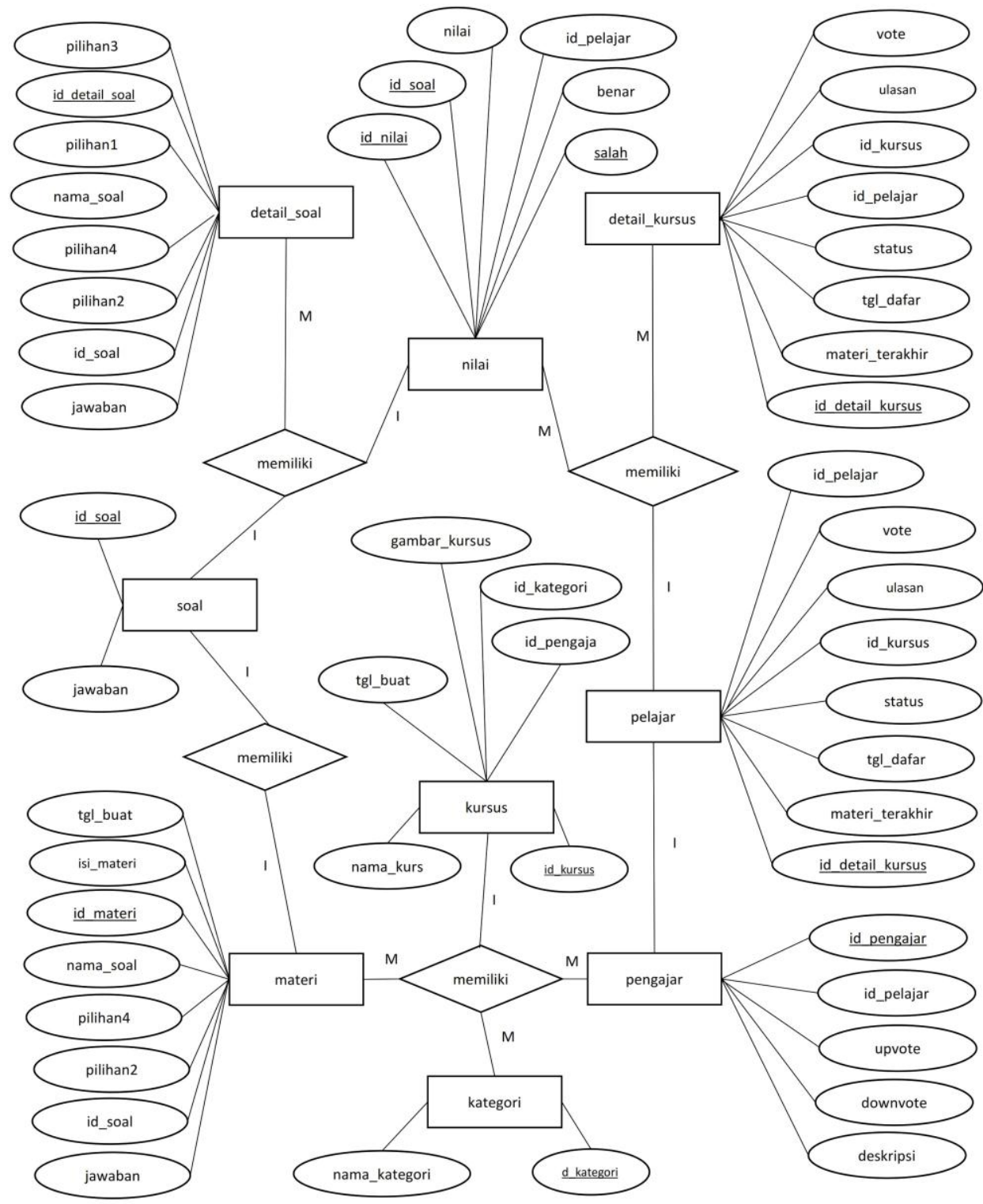

Sumber: Hasil Penelitian (2021)

Gambar 2. Entity Relationship Diagram 
Dari perancangan Entity Relationship Diagram didapatkan 8 entitas yang saling berhubungan membentuk satu kesatuan data dalam basis data. Pada ERD di bawah terdiri dari detail_soal yang memiliki attribute pilihan3, id_detail_soal, pilihan1, nama_soal, pilihan4, pilihan 2, id_soal, dan jawaban. Untuk nilai terdiri dari attribute: id_nilai, id_soal, nilai, id_pelajar, benar, dan salah, detail_kursus memiliki attribute vote, ulasan, id_kursus, id_pelajar, status, tgl_daftar, materi_terakhir, dan id_detail_kursus.

Untuk soal memiliki attribute id_soal dan jawaban, untuk materi terdir dari attribute tgl_buat, isi_materi, id_materi, nama_soal, pilihan4, pilihan2, id_soal, dan jawaban. Untuk kursus terdiri dari attribute nama_kursus dan id_kursus, untuk kategori terdiri dari attribute nama_kategori dan id_kategori. Untuk pengajar memilihi attribute id_pengjar, id_pelajar, upvote, downvote, dan deskripsi.

Pada ERD yang di tampilkan dibawah memiliki ketenttuan kardinalitas masing masing, yang menghubungkan satu tabel dengan tabel lain. Seperti kursus dengan materi yang memiliki kardinalitas one to many, yang berarti 1 kursus bisa memiliki banyak materi. Adalagi dari entitas kategori dengan kursus yang memiliki kardinalitas one to many yang berarti 1 kategori memiliki banyak kode kursus.

Pada entitas pengajar terhadap kursus memiliki kardinalitas one to many yang berarti 1 pengajar memiliki banyak kursus. Kemudian antara entitas pelajar dengan nilai memiliki kardinalitas one to many yang berarti 1 pelajar meiliki banyak nilai. Kemudian untuk entitas soal terhadap detail soal yang memiliki kardinalitas one to many yang memiliki arti 1 soal memiliki banyak detail soal. Untuk entitas pelajar terhadap detail kursus memiliki arti one to many yang berarti 1 pelajar memiliki banyak detail kursus, untuk lebih jelasnya dapat dilihat pada gambar 2 mengenai ERD.

\section{Spesifikasi File tabel Admin}

Pada spesifikasi table 1 dibawah, terdiri dari elemen data id admin dengan akroim id_admin dan memiliki type data varchar dengan ukuran size 5 dan sebagai kunci utama atau yang biasa disebut dengan primary key. Berikutnya ada username admin yang berfungsi sebagai identitas admin untuk melakukan login pada halaman admin, username admin memiliki type data varchar dengan ukuran 20. Kemudian ada lagi elemen data nama depan yang berfungsi sebagai identitas nama admin dengan ukuran type data data varchar 10. Kemudian adalagi elemen data nama belakang yang memiliki type data varchar ukuran 10. Terakhir pada spesifikasi file ada password admin yang berfungsi sebagai pengaman ketika admin melakukan login pada aplikasi, type datanya adalah varchar dengan ukuran size 10 yang dijelaskan pada tabel 1.

Tabel 1. Spesifikasi File Admin

\begin{tabular}{llllll}
\hline No & Eemen Data & Akronim Data & Type & Size & Keterangan \\
\hline 1 & ld Admin & id_admin & Varchar & 5 & PrimaryKey \\
\hline 2 & Username Admin & username_admin & Varchar & 20 & \\
\hline 3 & Nama Depan & nama_depan & Varchar & 10 & \\
\hline 4 & Nama Belakang & nama_belakang & Varchar & 30 & \\
\hline 5 & Passw ord Admin & password_admin & Varchar & 8 & \\
\hline
\end{tabular}

Sumber: Hasil Penelitian (2021)

\section{Spesifikasi File tabel Pelajar}

Pada spesifikasi file pada tabel 2 dibawah pelajar terdiri sembilan elemen data yang terdiri dari id pelajar dengan akronim id_pelajar dengan type data varchar dengan ukuran size 6 sebagai kunci utama atau yang bisa disebut dengan kunci primary key. Kunci utama tersebut dapat terhubung dengan tabel yang lain. Kemudian adalagi elemen data nama depan dengan akronim nama_depan dengan type data varchar dengan ukuran 20 , kemudian ada lagi elemen data nama belakang dengan type data varchar dengan ukuran 30. Pada field elemen data berikutnya terdapat password yang berfungsi sebagai pengaman ketika pelajar melakukan aktifitas di dalam sistem, password tersbut memiliki type data varchar dengan ukuran 8. Berikutnya elemen data foto profil yang terdiri dari type data varchar dengan ukuran 30. Berikutnya ada elemen data email yang memiliki akronim email dengan type data varchar dengan size 30. Pada jenis kelamin memiliki type data varchar dengan ukuran 10, berikutnya pada tanggal lahir memiliki type data date dengan ukuran 8. Pada field alamat memiliki akronim alamat dengan type data varchar dengan size 100 yang dijelaskan pada tabel 2. 
Tabel 2. Spesifikasi File Pelajar

\begin{tabular}{|c|c|c|c|c|c|}
\hline No & Eemen Data & Akronim Data & Type & Size & Keterangan \\
\hline 1 & Id Pelajar & id pelajar & Varchar & 6 & PrimaryKey \\
\hline 2 & Nama Depan & nama depan & Varchar & 20 & \\
\hline 3 & Nama Belakang & nama belakang & Varchar & 30 & \\
\hline 4 & Passw ord & password & Varchar & 8 & \\
\hline 5 & Foto Profil & foto_profil & Varchar & 30 & \\
\hline 6 & E-mail & email & Varchar & 30 & \\
\hline 7 & Jenis Kelamin & jenis kelamin & Varchar & 10 & \\
\hline 8 & Tanggal Lahir & tgl_lahir & Date & 8 & \\
\hline 9 & Alamat & alamat & Varchar & 100 & \\
\hline
\end{tabular}

Sumber: Hasil Penelitian (2021)

\section{Spesifikasi File tabel Pengajar}

Pada spesifikasi file pengajar memiliki 5 fileld yang terdiri dari idpengajar yang memiliki akronim id_pengajar dengan type data varchar ukuran size 11 dan sebagai kunci utama primary key. Adalagi elemen data upvote dan downvote dengan type data integer ukuran size 11. Berikutnya elemen data id pelajar dengan type data varchar ukuran size 6 yang memiliki kunci tamu foreign key, karena terhubung dengan tabel pelajar. Terakhir ada deskripsi pengajar yang memiliki type data varchar dan ukuran size 100.

Tabel 3. Spesifikasi File Pengajar

\begin{tabular}{clllll}
\hline No & Eemen Data & Akronim Data & Type & Size & Keterangan \\
\hline 1 & Id Pengajar & id_pengajar & Varchar & 6 & PrimaryKey \\
\hline 2 & Upvote & upvote & Int & 11 & \\
\hline 3 & Downvote & dow nvote & Int & 11 & \\
\hline 4 & Id Pelajar & id_pelajar & Varchar & 6 & Foreign Key \\
\hline 5 & Deskripsi Pengajar & deskripsi_pengajar & Varchar & 100 & \\
\hline
\end{tabular}

Sumber: Hasil Penelitian (2021)

\section{Spesifikasi File tabel Pengajar}

Tabel spesifikasi file tabel materi dibawah untuk menampilkan materi pelajaran pada sistem, dengan elemen data id materi dengan type data varchar yang memiliki ukuran size 6 dan sebagai kunci utama primary key. Pada elemen data nama materi memiliki type data varchar dengan ukuran size 30. Kemudian pada id kursus memiliki type data varchar dengan size 6 sebagai kunci tamu atau biasa di sebut dengan foreign key yang terhubung dengan tabel lain. Kemudian isi materi yang berisi materi yang disampaikan pada pelajaran yang memiliki type data varchar dengan ukuran size 200. Berikutnya pada elemen data tanggal dibuat dengan type data date dengan ukuran size 8 dan yang terakhir terdapat elemen data urut yang memiliki type data integer dengan ukuran 11.

Tabel 4. Spesifikasi File Materi

\begin{tabular}{clllll}
\hline No & \multicolumn{1}{c}{ Eemen Data } & \multicolumn{1}{c}{ Akronim Data } & \multicolumn{1}{c}{ Type } & \multicolumn{1}{c}{ Size } & Keterangan \\
\hline 1 & Id Materi & id_materi & Varchar & 6 & PrimaryKey \\
\hline 2 & Nama Materi & nama_materi & Varchar & 30 & \\
\hline 3 & Id Kursus & id_kursus & Varchar & 6 & Foreign Key \\
\hline 4 & Isi Materi & Isi_materi & Varchar & 200 & \\
\hline 5 & Url Video & url_video & Varchar & 50 & \\
\hline 6 & Tgl Dibuat & tgl_dibuat & Date & 8 & \\
\hline 7 & Urutan Materi & urut & Int & 11 & \\
\hline
\end{tabular}

Sumber: Hasil Penelitian (2021)

\section{Spesifikasi File tabel Pengajar}

Tabel spesifikasi nilai di bawah memiliki 6 field seperti id nilai yang memiliki type data varchar dengan ukuran size 6 sebagai primary key, kemudian ada id pelajar dengn type data varchar dengan size 6 sebagai kunci tamu foreign key karena terhubung dengan tabel lain. Kemudian pada id soal terdapat type data varchar dengan ukuran size 6 dan sebagai foreign key karena terhubung dengan tabel lain. Kemudian ada elemen deta benar dan salah yang terdiri dari type data integer dengan ukuran size 11. Kemudian terakhir elemen data nilai dengan type data integer dengan ukuran size 11. 
Tabel 5. Spesifikasi Nilai

\begin{tabular}{|c|c|c|c|c|c|}
\hline No & Eemen Data & Akronim Data & Type & Size & Keterangan \\
\hline 1 & Id Nilai & id nilai & Varchar & 6 & PrimaryKey \\
\hline 2 & Id Pelajar & id pelajar & Varchar & $\overline{6}$ & Foreign Key \\
\hline 3 & Id Soal & id soal & Varchar & 6 & Foreign Key \\
\hline 4 & Benar & benar & Int & 11 & \\
\hline 5 & Salah & salah & Int & 11 & \\
\hline 6 & Nilai & nilai & Int & 11 & \\
\hline
\end{tabular}

Sumber: Hasil Penelitian (2021)

\section{Implementasi Program}

Tampilan halaman pelajar, menampilkan beberapa menu dan informasi yang dapat diakses oleh pelajar yang telah melakukan pendaftaran sebagai pelajar seperti menu jelajah kursus untuk menampilkan semua kursus yang ada dan kursus terbaru untuk menampilkan materi kursus yang terkini, misal: PHP untuk Pemula Web Development Kepala Sekolah dan Vue JS 101 Web Development.

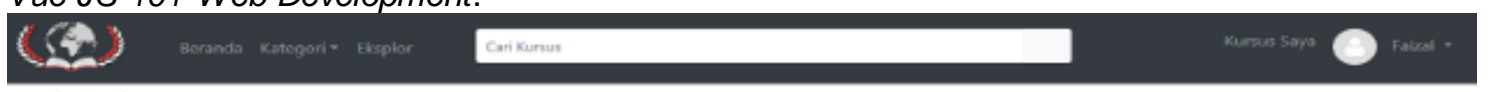

\section{Jelajah Kursus}

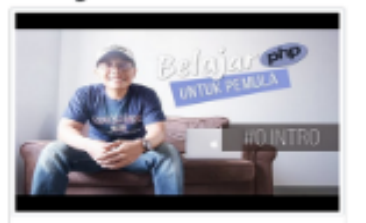

PHP Untuk Pemula Web Developmen

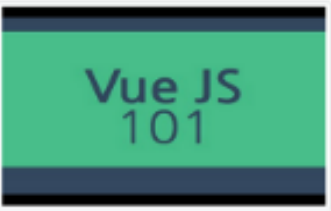

Vue IS 101

Web Developmemt
Fabsal Ardian Dutra

\section{Kursus Terbaru}

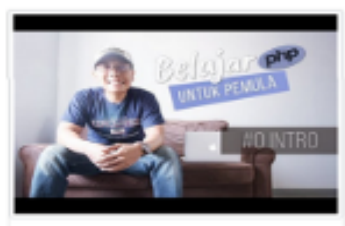

PHP Untuk Pemuli

Web Development

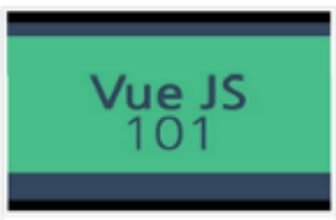

Vue JS 101

Web Development
Faleal Andian Putse

Sumber: Hasil Penelitian (2021)

Gambar 3. Tampilan Halaman Pelajar

Pada menu utama terdapat fitur materi yang meliputi judul dan kategori kursus, soal berupa latihan soal kursus yang diambil pelajar, laporan berupa skor nilai yang didapatkan pelajar setelah mengerjakan soal dan pengaturan mengenai informasi pelajar yang mengambil kursus. Fasilitas pencarian kursus untuk melakukan pencarian kursus yang diambil oleh pelajar yang sudah login, misal pelajar mengambil kursus dengan judul: mahir javascript dengan kategori web development.

Tampilan halaman pengajar (mengelola materi), menampilkan beberapa menu dan informasi yang dapat diakses oleh dalam melakukan aktifitas pada aplikasi. Menu utama yang menampilkan halaman pertama ketika program dijalankan, ada lagi menu materi yang berfungsi sebagai sarana materi yang akan diajarkan, adalagi mengenai menu soal yang berisi soal soal mata pelajaran yang akan dipelajari selama pembelajaran berlangsung. Adalagi menu laporan yang berisi lapran selama proses pembelajaran berlangung, ada lagi mengenai menu pengaturan untuk mengatur dari proses pembelajaran seperti mengatur waktu belajar, waktu ujian, dan mengatur materi yang akan di tampilkan pada proses pembelajaran. 


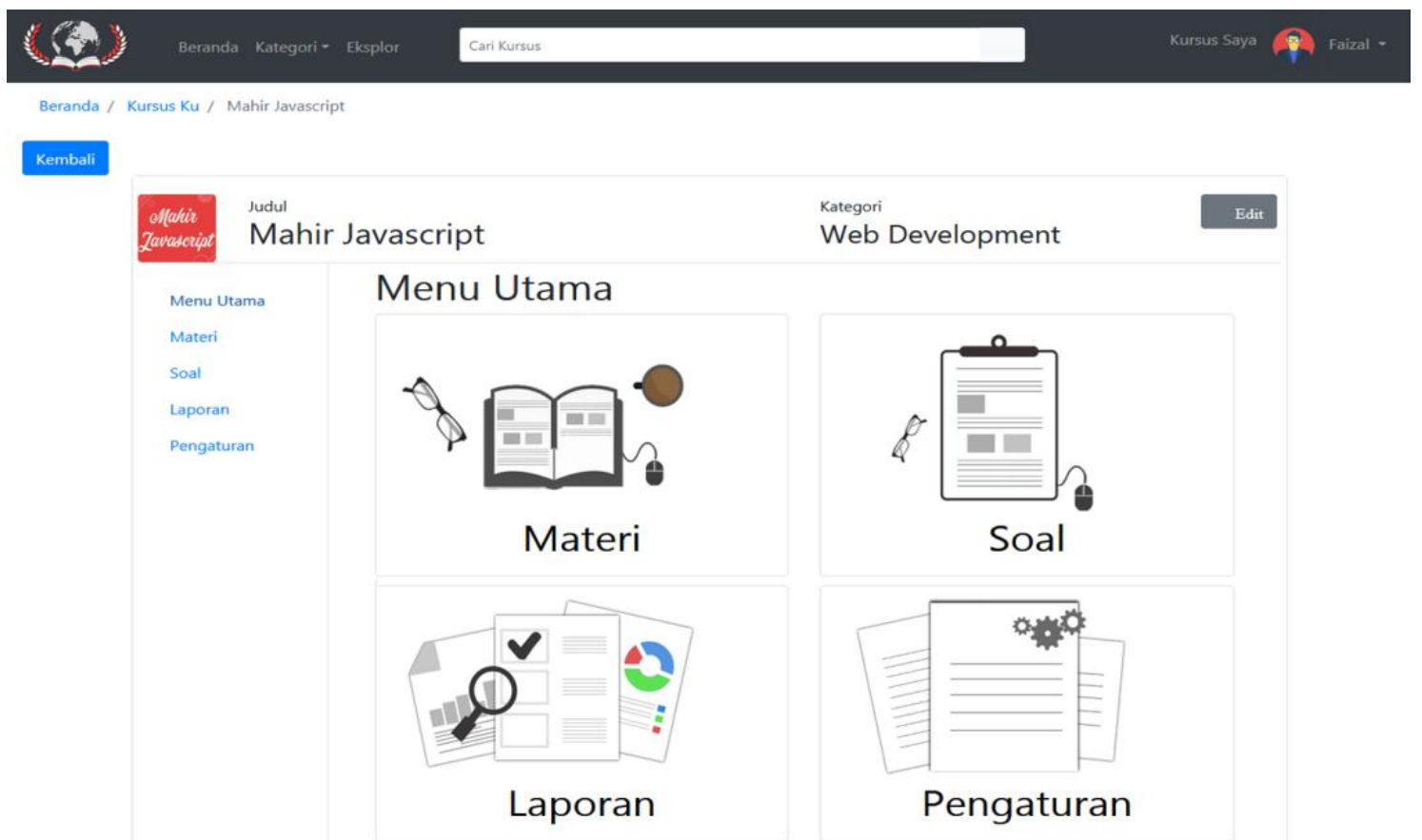

Sumber: Hasil Penelitian (2021)

Gambar 4. Tampilan Halaman Pengajar

Tampilan halaman admin, menampilkan beberapa menu dan informasi yang hanya dapat diakses oleh Admin untuk mengelola tiap proses yang terjadi didalam aplikasi, pada halaman admin terdiri dari beranda yang menampilkan halaman admin ketika aplikasi di buka, kerika menu data di klik akan menampilkan sub menu lagi yang terdiri dari data admin yang menampilkan data admin secara keseluruhan dan bisa juga menambah ataupun mengedit data admin. Kemudian ada data kategori yang berisi data kategori kursus. Kemudian ada data pelajar yang menampilkan informasi data pelajar seperti id pelajar, password, jenis kelamin, tanggal lahir, nama depan, nama belakang, alamat, email, foto profil. Kemudian adalagi menu data pengajar yang menyimpan data seperti id pengajar, upvote, deskripsi pengajar, downvote, dan ada id pelajar sebagai relasi ke tabel pelajar. Kemudian ada data kursus yang menampilkan data materi yang akan di kursuskan.

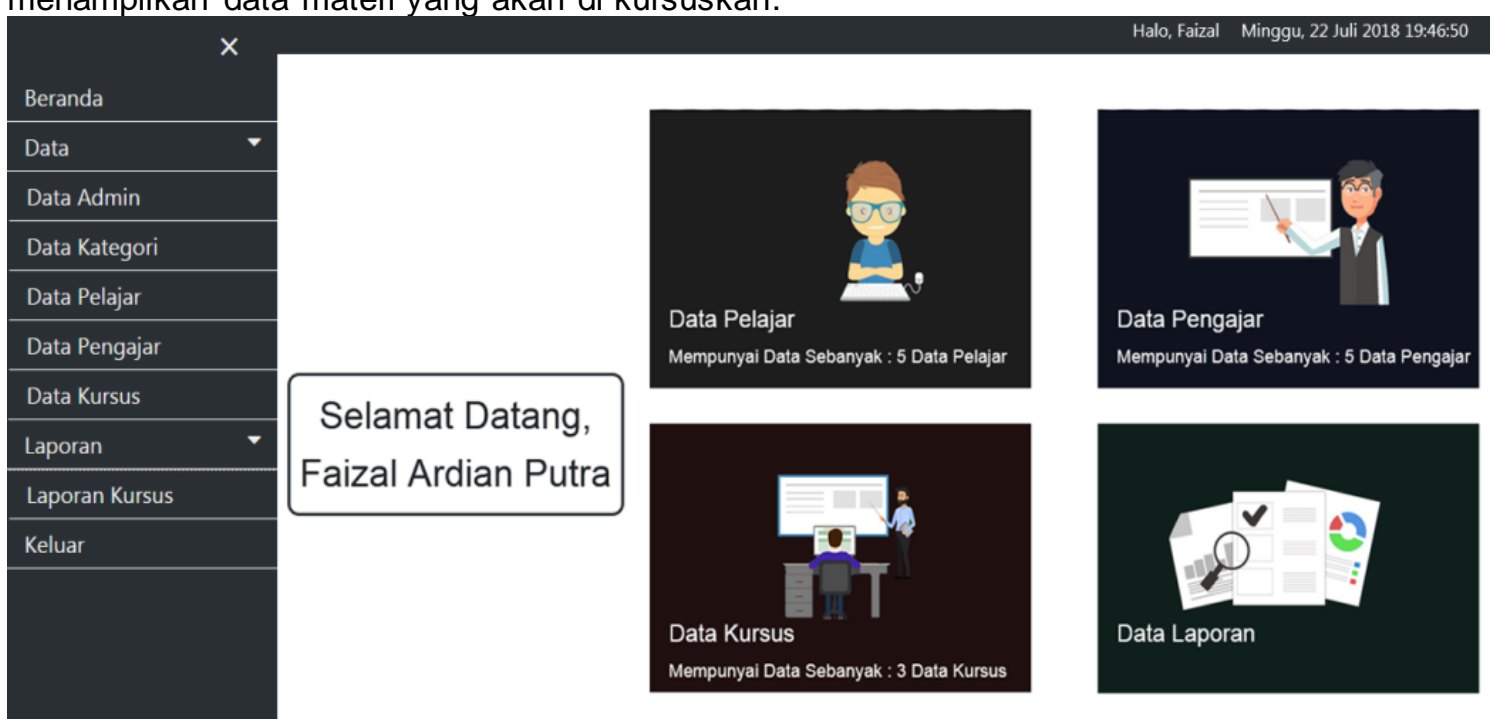

Sumber : Hasil Penelitian (2021)

Gambar 5. Tampilan Halaman Admin 
Adalagi menu laporan yang berisi laporan kurus selama proses kursus berlangsung seperti laporan data admin, laporan kategori, laporan pelajar, laporan pengajar, laporan data kursus dapat dilihat di gambar 5 .

\section{Kesimpulan}

Berdasarkan proses pengembangan sistem yang telah dilakukan dalam penelitian ini, maka dapat disimpulkan bahwa sistem pembelajaran secara daring dengan menggunakan metode Learner-Led Learning ini dapat digunakan dan menjadi solusi alternatif yang baik dalam menerapkan sistem pembelajaran secara daring bagi para pelajar. Tentunya sistem pembelajaran dengan metode ini dapat memenuhi harapan para pengajar agar anak didiknya dapat memiliki karakter yang mandiri, tangguh dan bertanggung jawab sehingga para pelajar tidak lagi bergantung pada keberadaan pengajar. Dari sisi pengajar, sistem ini memungkinkan pengajar untuk menjadi pelajar sehingga tidak hanya pelajar yang dapat meningkatkan pengetahuan, pengajar pun dapat menambah pengetahuan di bidang lainnya. Dengan adanya sistem ini para pelajar pun dapat berpikir kritis untuk terus menggali pengetahuan dan informasi yang dibutuhkan sesuai dengan otonomi pribadi pelajar itu sendiri. Untuk penelitian selanjutnya dapat dilengkapi dengan fitur-fitur yang interaktif seperti live streaming, live chat, Messanger Integration (notifikasi via smartphone) sehingga kenyamanan dalam proses pembelajaran dapat menjadi lebih baik.

\section{Referensi}

[1] F. Fatria and Husna. Tiflatul, "Analisis Proses Pembelajaran E-Learning Berbasis Edmodo Pada Mata Pelajaran Bahasa Indonesia Di Smk Multi Karya Medan," J. Pendidik. Bhs. dan Sastra Indones., vol. 3, no. 2, pp. 67-72, 2019.

[2] S. J. Kuryati, "Rancang Bangun Sistem E-Learning sebagai Sarana Pemberlajaran Sandra," J. Khatulistiwa Inform., vol. 4, no. 1, pp. 84-92, 2016, doi: 10.1089/pho.2010.2784.

[3] I. P. Sari, "Implementasi Pembelajaran Berbasis E-Learning Menggunakan Claroline," Research and Development Journal of Education," Res. Dev. J. Educ., vol. 4, no. 1, pp. 75-87, 2017, doi: 10.30998/rdje.v4i1.2070.

[4] N. Nuryadi, "Rancang Bangun Aplikasi Website E-Learning Pada Smk Respati 1 Jakarta," J. Tek. Komput. Univ. Bina Sarana Inform., vol. 4, no. 1, 2018.

[5] W. Hartanto, "Penggunaan E-Learning sebagai Media Pembelajaran," J. Pendidik. Ekon., vol. 10, no. 1, pp. 1-18, 2016.

[6] S. A. I. Zamaludin, W. Yusnaeni, "Perancangan Pembelajaran Jarak Jauh (E-Learning) Bahasa Jerman Berbasis Web," J. Prosisko, vol. 3, no. 2, pp. 20-25, 2016.

[7] I. M. S. I. P. Darmika, G. Gunatama, "Penggunaan E-Learning Dalam Pembelajaran Bahasa Indonesia Di Sma Negeri Bali Mandara," J. Pendidik. Bhs. dan Sastra Indones. Undiksha, vol. 260-272, no. 8, p. 2, 2019, doi: 10.23887/jjpbs.V8i2.20620.

[8] M. Salehudin, "Guru Mengadopsi Media Sosial Sebagai E-Learning Pada Pembelajaran Jarak Jauh," J. Mudarrisuna, vol. 10, no. 1, 2020, doi: 10.22373/jm.v10i1.6755.

[9] I. F. and D. N. Yunita, "Prosiding Samasta Seminar Nasional Bahasa Dan Sastra Indonesia Media Pembelajaran E-Learning Berbasis Schoology Pada Mata Pelajaran Bahasa Indonesia," in Seminar Nasional Bahasa dan Sastra Indonesia, 1AD, pp. 1-4.

[10] K. X T. Minat, B. Siswa, "Pengaruh Penggunaan Media Pembelajaran Sejarah Indonesia E- Learning Berbasis Quipper School Terhadap Minat dan Hasil Belajar Siswa Kelas X SMK N 04 Kendal Tahun Pelajaran 2016/2017," Indones. J. Hist. Educ., vol. 5, no. 2, pp. 60-67, 2017.

[11] D. Febriannisa and L. P. Hasugian, "Perancangan E-learning pada SMK Negeri 1 Bandung," J. Ultim. InfoSys, vol. 8, no. 2, pp. 62-68, 2018, doi: 10.31937/si.v8i2.613.

[12] R. Garrison, D., "Self-Directed Learning: Toward A Compherensive Model," Adult Educ. Q., vol. 48, no. 1, pp. 18-33, 1997.

[13] A. M. M. Uddin, N. Ahmed, "A Learner Model for Adaptable e-Learning," Int. J. Adv. Comput. Sci. Appl., vol. 14, no. 3-4, pp. 122-141, 2017.

[14] C. du Toit-Brits and C. M. van Zyl, "Self-directed learning characteristics: making learning personal, empowering and successful," Africa Educ. Rev., vol. 14, pp. 122-141, 2017.

[15] H. Khiat, "Academic performance and the practice of self-directed learning: The adult student perspective," J. Furth. High. Educ., vol. 41, no. 1, pp. 44-59, 1017. 
BINA INSANI ICT JOURNAL ISSN: 2355-3421 (Print) ISSN: 2527-9777 (Online); 156 - 165

[16] E. Sumuer, "Factors related to college students' self-directed learning with technology," Australas. J. Educ. Technol., vol. 34, no. 4, pp. 29-43, 2018.

[17] Yurindra, Software Engineering, Yogyakarta: Deepublish, 2017. 